\title{
Selenization of Basil and Cilantro Through Foliar Applications of Selenate-selenium and Selenite-selenium
}

\author{
Dean A. Kopsell ${ }^{1,5}$, Carl E. Sams², T. Casey Barickman³, \\ and Dennis E. Deyton ${ }^{2}$ \\ Plant Sciences Department, The University of Tennessee, 252 Ellington Plant \\ Sciences, 2431 Joe Johnson Drive, Knoxville, TN 37996-4561
}

\author{
David E. Kopsell ${ }^{4}$ \\ Department of Agriculture, Illinois State University, Normal, IL 61790
}

Additional index words. Coridandrum, herbal crops, Ocimum, selenium

\begin{abstract}
Selenium (Se) is an essential mammalian micronutrient. Adult humans have a daily requirement of 55 to $70 \mu \mathrm{g} /$ day Se depending on sex and pregnancy/lactation for females. In addition, recent studies have shown health benefits with dietary Se supplementation of 100 to $200 \mu \mathrm{g} /$ day Se. However, daily intakes in humans greater than $900 \mu \mathrm{g}$ Se will result in toxicity called selenosis. Although not essential in plant nutrition, some species can bioaccumulate Se. Brassica and Allium species became prime candidates for Se enrichment because of their ability to accumulate and tolerate high concentrations of Se in edible tissues; however, there is now concern that these species are too efficient at selenization and overconsumption of their selenized tissues could result in selenosis. Herbal crop species are consumed regularly in the diet for their culinary flavor attributes. Basil (Ocimum basilicum L.) and cilantro (Coridandrum sativum L.) are not classified as Se accumulators. Therefore, a study was undertaken to determine the potential to selenize basil and cilantro through foliar Se applications to consistently supplement diets with nutritionally beneficial levels of Se. Plants of each species were grown in both growth chamber and field environments and treated with foliar applications $(5 \mathrm{~mL}$ per plant) of selenate-Se and selenite-Se at concentrations of $0,2,4$, 8,16 , and $32 \mathrm{mg} \cdot \mathrm{L}^{-1} \mathrm{Se}$. Crops received three separate foliar applications at $\approx 5$-day intervals beginning 24 to 28 days after planting for the growth chamber plants and 50 days after planning for the field environment. Selenium accumulation in both basil and cilantro leaf tissues increased linearly under both selenate-Se $(P \leq 0.001)$ and selenite-Se $(P \leq 0.001)$ foliar treatments in growth chamber and field evaluations. Maximum Se leaf tissue concentrations for basil and cilantro ranged from 13 to $55 \mu \mathrm{g} \cdot \mathrm{g}^{-1}$ Se dry weight. Selenization of basil and cilantro is possible through foliar Se applications, and $\mathrm{Se}$ fortification of herbal crops may provide alternative delivery systems in human diets.
\end{abstract}

Selenium (Se) is an essential micronutrient for maintaining mammalian health (Finley, 2007; Mayland et al., 1989). Epidemiological studies have pointed to inverse associations between nutritional Se status and potential incidences of certain cancers (Combs and Gray, 1998; Ip and Lisk, 1994), cardiovascular diseases (Korpela, 1993; Old-

\footnotetext{
Received for publication 25 June 2008. Accepted for publication 3 Sept. 2008.

This research was funded through a professional development awards program administered by the University of Tennessee Graduate School.

The cost of publishing this paper was defrayed in part by the payment of page charges. Under postal regulations, this paper therefore must be hereby marked advertisement solely to indicate this fact. ${ }^{1}$ Associate Professor.

${ }^{2}$ Professor.

${ }^{3}$ Research Associate and current Graduate Student. ${ }^{4}$ Assistant Professor.

${ }^{5}$ To whom reprint requests should be addressed; e-maildkopsell@utk.edu.
}

field, 1991), and problems with immune system functions (Baum et al., 1997; RyanHarshman and Aldoori, 2005). Currently, there are more than 40 disease and health abnormalities in humans related to Se deficiency (Clark et al., 1998). Average Se intakes in most countries are sufficient to meet U.S. recommended dietary allowances of 55 to $70 \mu \mathrm{g} / \mathrm{d}$ Se for adults depending on sex and pregnancy/lactation for females (Clark et al., 1998; Finley, 2007). However, individuals living in several countries such as New Zealand, Finland, the United Kingdom, and areas of China have inadequate Se intake and these countries have instituted crop Se fertilization strategies to help fortify both animal and human diets (Finley, 2007; Hawkesford and Zhao, 2007; Reilly, 1998).

Because the soil is the primary source of $\mathrm{Se}$, levels of Se in plant foods and in the animals that consume them show considerable variation as a result of fluctuations in soil Se that occurs throughout the world. Increasing tissue Se concentrations in edible crops through Se fertilization strategies would improve the overall Se contribution to human diets (Finley, 2007; Kopsell and Randle, 1999). Moreover, consumption of selenized vegetables can be an effective way to supplement necessary levels of Se in the human diet (Finley, 2007; Ip and Lisk 1994). Several strategies are used to fortify crops with Se. Most of these involve applications of different Se chemical forms to the soil matrix. However, soil $\mathrm{pH}$, aeration, water levels, organic matter, and oxidation-reduction conditions all have an impact on the form of $\mathrm{Se}$ present in the soil and its availability to plants (Adriano, 1986; Gissel-Nielsen et al., 1984; Kopsell and Kopsell, 2006). This creates potential problems with plant fortification activities in which applications of Se fertilizers are made to the soil matrix. It also complicates recommendations for the consumption of specific foods that may accumulate high concentrations of Se from natural soil Se deposits (Finley, 2007). Foliar applications of Se to crop plants may eliminate soil matrix interferences and provide a more efficient mechanism to fortify crops with Se.

Foliar Se applications have been used to fortify tissues of buckwheat (Fagopyrum esculentium Moench; Smrkolj et al., 2006; Stibilj et al., 2004), chicory (Cichorium intybus L.; Germ et al., 2007), potato (Solanum tuberosum L.; Poggi et al., 2000), pumpkin (Cucurbita pepo L.; Stibilj et al., 2004), and rice (Oryza sativa L.; Fang et al., 2008) with essential Se for human diets. Herbal crops are added to foods in small quantities for their flavor attributes. The regularity with which herbs are used in culinary food preparations, and their rates of consumption, may make them good candidates for Se supplementation to human diets. However, most herbal crops are not classified as Se accumulators, and this necessitates the need to investigate tolerances to different Se forms and concentrations. Therefore, the objectives of this study were to evaluate the potential to fortify basil and cilantro shoot tissues through foliar application of both selenate-Se and selenite-Se at different Se concentrations in both controlled environment and field conditions.

\section{Materials and Methods}

The ability to selenize 'Genovese' basil and 'Santo' cilantro (Johnny's Selected Seed, Winslow, ME) was tested in both growth chamber and field environments. Seeds of 'Genovese' basil were sown on 23 Jan. 2007 in $10.2-\mathrm{cm}$ pots filled with a commercial soilless medium (BM-1; Berger Horticulture, Saint Modeste, Quebec, Canada) and grown in a controlled environment (Model E15; Conviron, Winnipeg, Manitoba, Canada) at a 16 -h photoperiod under $23 / 18{ }^{\circ} \mathrm{C}$ (day/ night) temperatures. Irradiation at the canopy height was $500 \mu \mathrm{mol} \cdot \mathrm{m}^{-2} \cdot \mathrm{s}^{-1}$ (LI-188B; LICOR, Inc., Lincoln, NE). Seeds were watered daily with $60 \mathrm{~mL}$ of tap water. Starting 31 Jan. 2007, seedlings were fertilized with 60 $\mathrm{mL}$ of a nutrient solution (Hoagland and 
Arnon, 1950) and were fertilized every 7 $d$ until the end of the study. Elemental concentrations of the fertilizer solution were $\left(\mathrm{mg} \cdot \mathrm{L}^{-1}\right)$ : nitrogen $(\mathrm{N} ; 210.0)$, phosphorus $(\mathrm{P}$; $30.6)$, potassium $(\mathrm{K} ; 234.6)$, calcium $(\mathrm{Ca}$; 160.4), magnesium (Mg; 49.2), sulfur (S; 64.0), iron ( $\mathrm{Fe} ; 1.0)$, boron (0.5), molybdenum (Mo; 0.01), copper ( $\mathrm{Cu} ; 0.02)$, manganese $(\mathrm{Mn} ; 0.5)$, and zinc $(\mathrm{Zn} ; 0.05)$. Four individual plants represented each of the 11 foliar treatments. Treatments were randomized within each of four environmental growth chambers, which served as experimental replications. Selenate-Se was applied as $\mathrm{Na}_{2} \mathrm{SeO}_{4}$ at concentrations of $2,4,8,16$, and $32 \mathrm{mg} \cdot \mathrm{L}^{-1} \mathrm{Se}$. Selenite-Se was applied as $\mathrm{Na}_{2} \mathrm{SeO}_{3}$ at concentrations of $2,4,8,16$, and $32 \mathrm{mg} \cdot \mathrm{L}^{-1} \mathrm{Se}$. All pots were sprayed with 5.0 $\mathrm{mL}$ of the treatment solution using a household handheld sprayer. Control pots were sprayed with deionized water at the same rate. All treatment solutions also contained $0.01 \%$ of a nonionic surfactant (Triton X100; Fisher Scientific, Pittsburgh, PA). Foliar Se treatments were applied to the basil plants at the emergence of third true leaf whorl on 16 Feb. 2007. Foliar treatments were applied twice more on 22 and 27 Feb. 2007. Basil plants were harvested on 5 Mar. 2007. Shoot tissues from four plants were bulked for each treatments, tissues were washed with a nonionic, phosphate-free detergent, double rinsed with deionized water, and dried in a forced-air drying oven set at $70{ }^{\circ} \mathrm{C}$.

Seeds of 'Santo' cilantro were sown on 20 Mar. 2007 in 10.2-cm pots filled with a commercial soilless medium (BM-1; Berger Horticulture) and grown in a controlled environment (Model E15; Conviron) as described previously. Starting 5 Apr. 2007, seedlings were fertilized with $60 \mathrm{~mL}$ of a nutrient solution (described previously) and were fertilized every $7 \mathrm{~d}$ until the end of the study. Selenium treatment concentrations, experimental replications, randomizations of treatment pots, and foliar applications of Se treatments were the same as described previously for basil. Foliar Se treatments were applied to the cilantro plants at the emergence of fifth true leaf whorl on 17 Apr. 2007. Foliar treatments were applied twice more on 22 and 27 Apr. 2007. Cilantro plants were harvested on 4 May 2007. Shoot tissues from four plants were bulked for each treatment, tissues were washed with a nonionic, phosphate-free detergent, doublerinsed with deionized water, and dried in a forced-air dying oven set at $70{ }^{\circ} \mathrm{C}$.

For field evaluations, 'Genovese' basil and 'Santo' cilantro were seeded into 25-cell flats holding a commercial soilless media (BM-1; Berger Horticulture) on 10 Apr. 2007 in a greenhouse in Knoxville, TN (lat. $\left.35.98^{\circ} \mathrm{N}\right)$. Seeds were watered daily and fertilized with a fertilizer solution containing (mg. $\left.\mathrm{L}^{-1}\right)$ : N (105.0), P (15.3), K (117.3), Ca (80.2), Mg (24.6), S (32.0), Fe (0.5), B (0.25), Mo (0.005), Cu (0.01), Mn (0.25), and $\mathrm{Zn}$ (0.025) on 24 Apr. and 1 May 2007. Seedlings were transplanted to the field on 9 May 2007. Transplants were set in double rows on black plastic $86.4 \mathrm{~cm}$ in width covering a Sequatchie silt loam soil (fine-loamy, siliceous, thermic Humic Hapudult). Soil samples were taken from the plots before transplanting and measured for Se concentrations. A $0.3-\mathrm{g}$ subsample of ground soil was combined with $9 \mathrm{~mL} \mathrm{HNO}_{3}(70 \%)$ and 3 $\mathrm{mL}$ of $\mathrm{HCl}$ and sealed in a closed vessel microwave digestion system (ETHOS series; Milestone Inc., Shelton, CT). Digestions were diluted with $2 \% \mathrm{HNO}_{3} / 0.5 \% \mathrm{HCl}$ (v/ $\mathrm{v})$, and $\mathrm{Se}$ was measured using an Agilent 7500ce ICP-MS system (Agilent Technologies, Wilmington, DE). Equipment parameters are described subsequently for the leaf tissue samples. Within-row plant spacings were $25.4 \mathrm{~cm}$, between-row plant spacings were $50.8 \mathrm{~cm}$, and rows were set $3.1 \mathrm{~m}$ on center. Preplant fertilizer applications were $112.1 \mathrm{~N}-43.6 \mathrm{P}-83.1 \mathrm{~K}$ (in $\mathrm{kg} \cdot \mathrm{ha}^{-1}$ from potassium nitrate, monoammonium phosphate, and muriate of potash). The plot also received two fertigation applications of $14.0 \mathrm{~kg} \cdot \mathrm{ha}^{-1} \mathrm{~N}$ (as ammonium nitrate) through drip irrigation lines 14 and $28 \mathrm{~d}$ after transplanting. Treatment plots consisted of four individual plants for each species and were arranged in a randomized complete block replicated four times. Eleven foliar Se treatments consisted of selenate-Se applied as $\mathrm{Na}_{2} \mathrm{SeO}_{4}$ at concentrations of $2,4,8,16$, and $32 \mathrm{mg} \cdot \mathrm{L}^{-1} \mathrm{Se}$; selenite-Se applied as $\mathrm{Na}_{2} \mathrm{SeO}_{3}$ at concentrations of $2,4,8,16$, and $32 \mathrm{mg} \cdot \mathrm{L}^{-1} \mathrm{Se}$; and control pots sprayed with deionized water. All plots were sprayed with $5.0 \mathrm{~mL}$ of the treatment solutions using a household handheld sprayer. All treatment solutions also contained $0.01 \%$ of a nonionic surfactant. Foliar treatments were applied on 30 May, 4 June, and 8 June 2007. Cilantro plants were harvested on 14 June 2007, and basil plants were harvested on 15 June 2007. Shoot tissues from four plants were bulked for each treatment, tissues were washed with a nonionic, phosphate-free detergent, doublerinsed with deionized water, and dried in a forced-air dying oven set at $70{ }^{\circ} \mathrm{C}$.

Dried leaf tissues were ground using a household spice grinder (Model GX4100; Krups, Medford, MA). A 0.5-g subsample of ground tissue was combined with $10 \mathrm{~mL}$ $\mathrm{HNO}_{3}(70 \%)$ and sealed in a closed-vessel microwave digestion system (ETHOS series, Milestone Inc.). Digestion procedures followed those for organically based matrices (U.S. Environmental Protection Agency, 1996). Digestions were diluted with $2 \%$ $\mathrm{HNO}_{3} / 0.5 \% \mathrm{HCl}(\mathrm{v} / \mathrm{v})$, and elemental measurements were made using an Agilent $7500 \mathrm{ce}$ ICP-MS system (Agilent Technologies). The ICP-MS system was equipped with an octapole collision/reaction cell, Agilent 7500 ICP-MS ChemStation software, a Micromist nebulizer, a water-cooled quartz spray chamber, and an CETAC (ASX-510; CETAC Inc., Omaha, NE) autosampler. The instrument was optimized daily in terms of sensitivity ( $\mathrm{Li}, \mathrm{Y}, \mathrm{Tl}$ ), level of oxide (Ce), and doubly charged ion $(\mathrm{Ce})$ using a tuning solution containing $10 \mu \mathrm{g} \cdot \mathrm{L}^{-1}$ of $\mathrm{Li}, \mathrm{Y}, \mathrm{Tl}, \mathrm{Ce}$, and $\mathrm{Co}$ in a $2 \% \mathrm{HNO}_{3} / 0.5 \% \mathrm{HCl}(\mathrm{v} / \mathrm{v})$ matrix.
Data were subjected to analysis of variance, regression, and contrast procedures to test the significance of main effects and possible interactions using SAS statistical software (Version 9.2; SAS Institute, Cary, NC).

\section{Results}

Growth chamber evaluation. Selenium accumulation in basil shoot tissues grown in a controlled environment responded to $\mathrm{Se}$ form $(\mathrm{F}=14.7 ; P \leq 0.001)$, foliar $\mathrm{Se}$ treatment concentration $(\mathrm{F}=449.3 ; P \leq$ 0.001 ), and to the interaction between $\mathrm{Se}$ form and Se treatment concentration $(\mathrm{F}=$ 11.6; $P \leq 0.001)$. Mean shoot tissue $\mathrm{Se}$ concentrations were $0.0,3.0,5.1,11.3,21.0$, and $55.7 \mu \mathrm{g} \cdot \mathrm{g}^{-1}$ Se dry mass $(\mathrm{DM})$ for the foliar selenate-Se treatment concentrations of $0,2,4,8,16$, and $32 \mathrm{mg} \cdot \mathrm{L}^{-1} \mathrm{Se}$, respectively. Basil shoot tissue Se concentrations increased linearly [selenate-Se $=-1.57+1.71$ (trt); $\left.R^{2}=0.98\right]$ with increasing selenate-Se concentrations of the foliar sprays (Fig. 1). Basil shoot tissue Se concentrations averaged $0.0,2.7,5.7,8.4,21.8$, and $41.5 \mu \mathrm{g} \cdot \mathrm{g}^{-1} \mathrm{Se} \mathrm{DM}$ for the foliar selenite-Se treatment concentrations of $0,2,4,8,16$, and $32 \mathrm{mg} \cdot \mathrm{L}^{-1} \mathrm{Se}$, respectively. Shoot tissue Se concentrations for basil increased linearly [selenite-Se = $-0.31+1.31$ (trt); $\left.R^{2}=0.98\right]$ with increasing selenite-Se concentrations of the foliar sprays (Fig. 1).

Selenium accumulation in cilantro shoot tissues grown in a controlled environment responded to $\mathrm{Se}$ form $(\mathrm{F}=45.9 ; P \leq 0.001)$, foliar Se treatment concentration $(\mathrm{F}=64.2$; $P \leq 0.001)$, and to the interaction between $\mathrm{Se}$ form and Se treatment concentration $(\mathrm{F}=$ 13.9; $P \leq 0.001)$. Mean shoot tissue $\mathrm{Se}$ concentrations were $0.0,1.5,1.8,3.2,4.9$, and $9.3 \mu \mathrm{g} \cdot \mathrm{g}^{-1}$ Se DM for the foliar selenateSe treatment concentrations of $0,2,4,8,16$, and $32 \mathrm{mg} \cdot \mathrm{L}^{-1} \mathrm{Se}$, respectively. Cilantro shoot tissues Se concentrations increased linearly [selenate-Se $=0.78+0.27(\operatorname{trt}) ; R^{2}=0.89$ ] with increasing selenate-Se concentrations of the foliar sprays (Fig. 2). Cilantro shoot tissue Se concentrations averaged 0.0, 2.0, 4.2, 5.8, 14.2, and $33.9 \mu \mathrm{g} \cdot \mathrm{g}^{-1} \mathrm{Se} \mathrm{DM}$ for the foliar selenite-Se treatment concentrations of 0,2 , 4, 8, 16, and $32 \mathrm{mg} \cdot \mathrm{L}^{-1} \mathrm{Se}$, respectively. Shoot tissues Se concentrations for cilantro increased linearly [selenite-Se $=-0.64+1.04$ (trt); $\left.R^{2}=0.95\right]$ with increasing selenite-Se concentrations of the foliar sprays (Fig. 2).

Field evaluation. Acid-extractable soil Se concentrations for the field environment averaged $0.35 \mathrm{mg} \cdot \mathrm{kg}^{-1}$ and were within the range of most nonseleniferous soils in the United States (Adriano, 1986). Selenium accumulation in field-grown basil shoot tissues responded to foliar Se treatment concentration $(\mathrm{F}=51.4 ; P \leq 0.001)$, but not to Se form or the interaction between $\mathrm{Se}$ form and $\mathrm{Se}$ treatment concentration. Mean shoot tissue Se concentrations were $0.0,1.9,3.7,6.2$, 12.4, and $22.9 \mu \mathrm{g}^{-\mathrm{g}^{-1}} \mathrm{Se} \mathrm{DM}$ for the foliar selenate-Se treatment concentrations of $0,2,4$, 8,16 , and $32 \mathrm{mg} \cdot \mathrm{L}^{-1} \mathrm{Se}$, respectively. Basil 


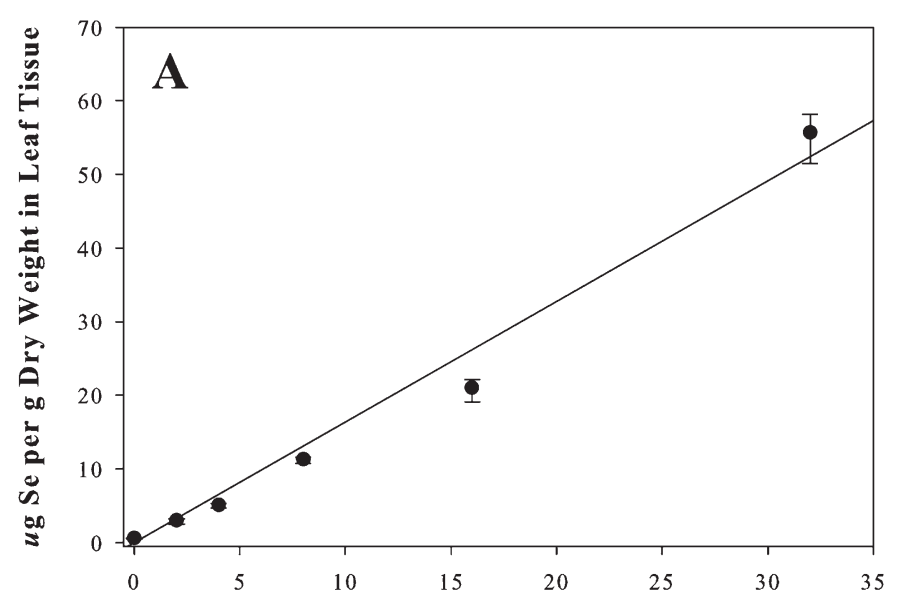

Foliar selenate-Se treatments (mg Se per $L$ )

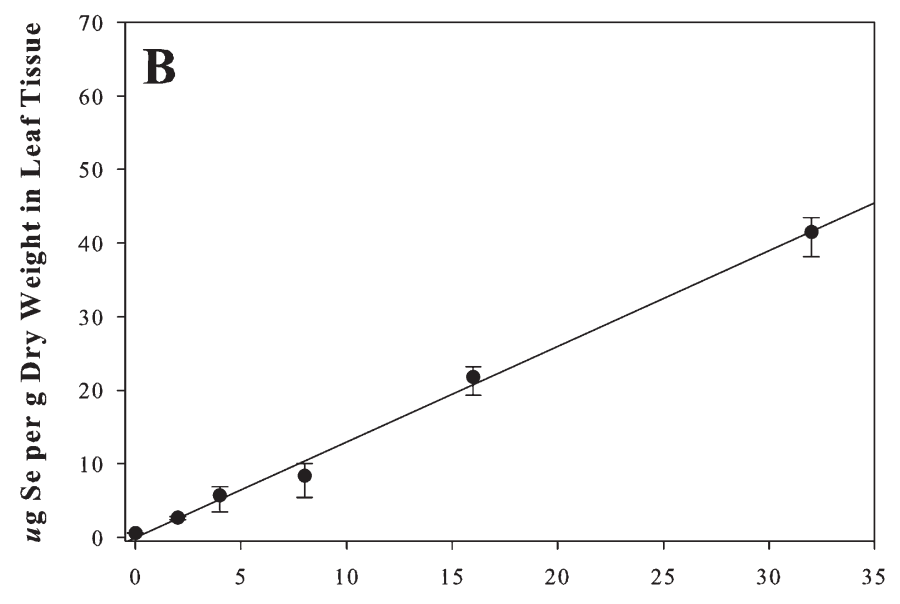

Foliar selenite-Se treatments (mg Se per L)

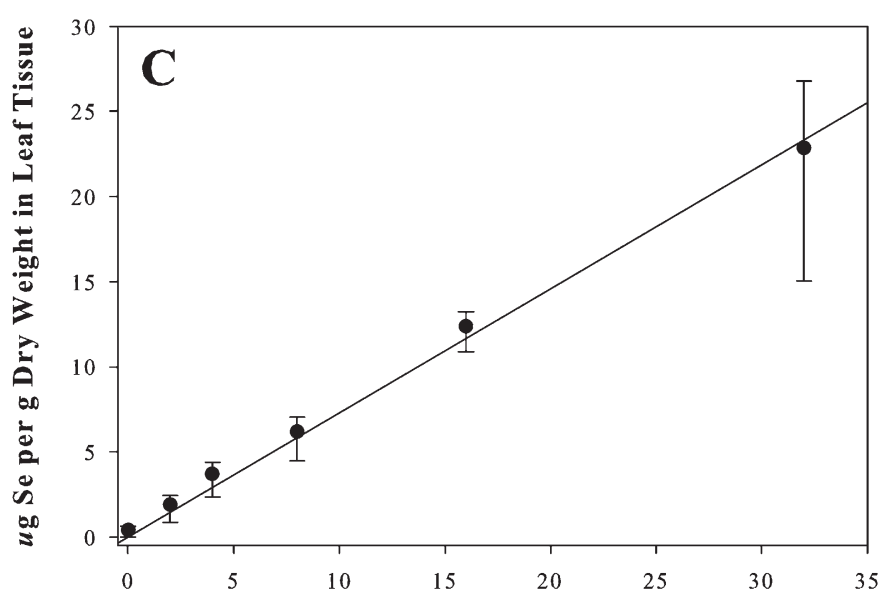

Foliar selenate-Se treatments (mg Se per L)

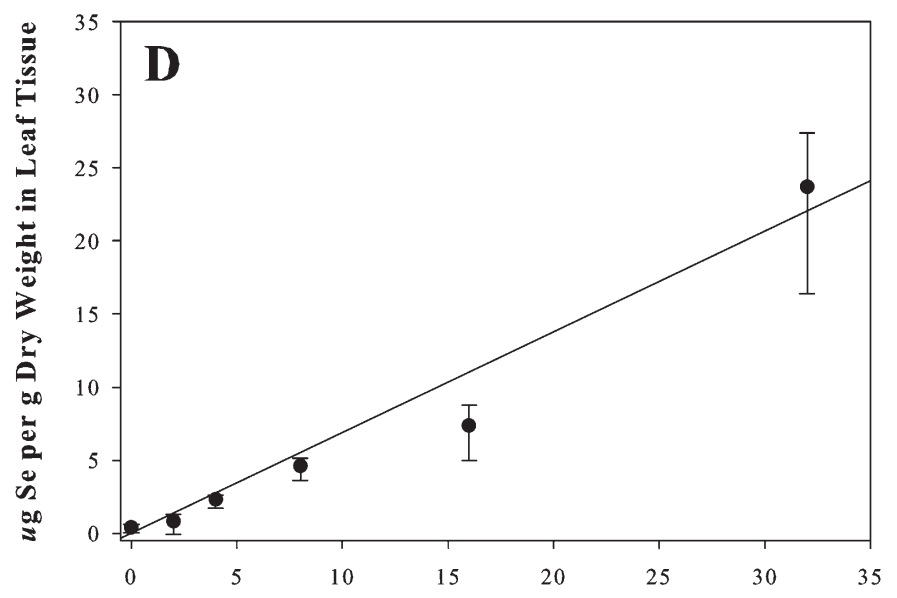

Foliar selenite-Se treatments (mg Se per L)

Fig. 1. Selenium (Se) accumulation in the leaf tissue of 'Genovese' basil under foliar applications of $0.0,2.0,4.0,8.0,16.0$ and $32.0 \mathrm{mg} \cdot \mathrm{L}^{-1} \mathrm{Se}$ in a growth chamber environment with Se applied as (A) sodium selenate [selenate-Se $=-1.57+1.71\left(\right.$ trt); $\left.R^{2}=0.98\right]$ and as $(\mathbf{B})$ sodium selenite [selenite-Se $=-0.31+1.31$ (trt); $R^{2}=0.98$ ], and in a field environment with Se applied as $(\mathbf{C})$ sodium selenate [selenate-Se $=-0.69+0.70$ (trt); $R^{2}=0.87$ ] and as $(\mathbf{D})$ sodium selenite [selenite$\left.\mathrm{Se}=-0.82+0.73(\operatorname{trt}) ; R^{2}=0.86\right]$. Values represent treatment means with SE bars.

shoot tissue Se concentrations increased linearly [selenate-Se $=-0.69+0.70(\operatorname{trt}) ; R^{2}=$ $0.87]$ with increasing selenate-Se concentrations of the foliar sprays (Fig. 1). Basil shoot tissue Se concentrations averaged 0.0, 0.8, 2.3, 4.6, 7.4, and $23.7 \mu \mathrm{g} \cdot \mathrm{g}^{-1} \mathrm{Se} \mathrm{DM}$ for the foliar selenite-Se treatment concentrations of $0,2,4,8,16$, and $32 \mathrm{mg} \cdot \mathrm{L}^{-1} \mathrm{Se}$, respectively. Shoot tissue Se concentrations for basil increased linearly [selenite-Se $=-0.82+0.73$ (trt); $\left.R^{2}=0.86\right]$ with increasing selenite-Se concentrations of the foliar sprays (Fig. 1).

Selenium accumulation in field-grown cilantro shoot tissues responded to Se form (F $=22.8 ; P \leq 0.001)$, foliar Se treatment concentration $(\mathrm{F}=137.5 ; P \leq 0.001)$, and to the interaction between $\mathrm{Se}$ form and $\mathrm{Se}$ treatment concentration $(\mathrm{F}=4.9 ; P=$ 0.002). Mean shoot tissue Se concentrations were $0.0,3.8,6.3,12.9,28.2$, and $49.5 \mu \mathrm{g} \cdot \mathrm{g}^{-1}$ Se DM for the foliar selenate-Se treatment concentrations of $0,2,4,8,16$, and $32 \mathrm{mg} \cdot \mathrm{L}^{-1}$ $\mathrm{Se}$, respectively. Cilantro shoot tissue $\mathrm{Se}$ concentrations increased linearly [selenate$\mathrm{Se}=1.22+1.54$ (trt); $\left.R^{2}=0.97\right]$ with increasing selenate-Se concentrations of the foliar sprays (Fig. 2). Cilantro shoot tissue Se concentrations averaged 0.0, 3.0, 5.5, 7.8, 18.6, and $34.8 \mu \mathrm{g} \cdot \mathrm{g}^{-1}$ Se DM for the foliar selenite-Se treatment concentrations of 0,2 , 4, 8, 16, and $32 \mathrm{mg} \cdot \mathrm{L}^{-1} \mathrm{Se}$, respectively. Shoot tissue Se concentrations for cilantro increased linearly [selenite-Se $=0.99+1.06$ (trt); $\left.R^{2}=0.91\right]$ with increasing selenite-Se concentrations of the foliar sprays (Fig. 2).

\section{Discussion}

Selenization was effective for basil and cilantro grown in both a controlled environment and a field environment. Tissue Se concentrations in basil and cilantro increased in response to increasing foliar Se treatment concentrations from both selenate-Se and selenite-Se forms in both environments. Selenization was more effective for the basil tissues, as compared with the cilantro, in the controlled environment. Selenate-Se was more effective at selenizing basil tissue than selenite-Se in the controlled environment; however, the opposite was true for cilantro selenization (Figs. 1 and 2). It may be that cilantro has the ability to absorb more foliar selenite-Se than basil. Genetic differences for Se uptake and accumulation has been reported among many different plant species (Kopsell and Kopsell, 2006). Maximum Se tissue accumulation across both $\mathrm{Se}$ forms for basil and cilantro in the controlled environment averaged 55.0 and $33.9 \mu \mathrm{g} \cdot \mathrm{g}^{-1}$ Se DM, respectively. Cilantro accumulated higher Se concentrations than basil when the study was conducted in the field. This may be the result of the morphology differences between the species in the study. Cilantro grows in a tight, horizontal rosette, whereas basil has a bush-type growth habit. In the field, the horizontal rosette of the cilantro may have intercepted more of the foliar Se sprays. Maximum Se tissue accumulation for basil and cilantro in the field environment averaged 23.7 and $49.5 \mu \mathrm{g} \cdot \mathrm{g}^{-1} \mathrm{Se} \mathrm{DM}$, respectively (Figs. 1 and 2).

The conversion of selenate-Se into organic Se compounds is believed to occur in the chloroplasts, where it enters into normal S metabolic pathways (Brown and Shrift, 1982; White et al., 2004). Selenate-Se 

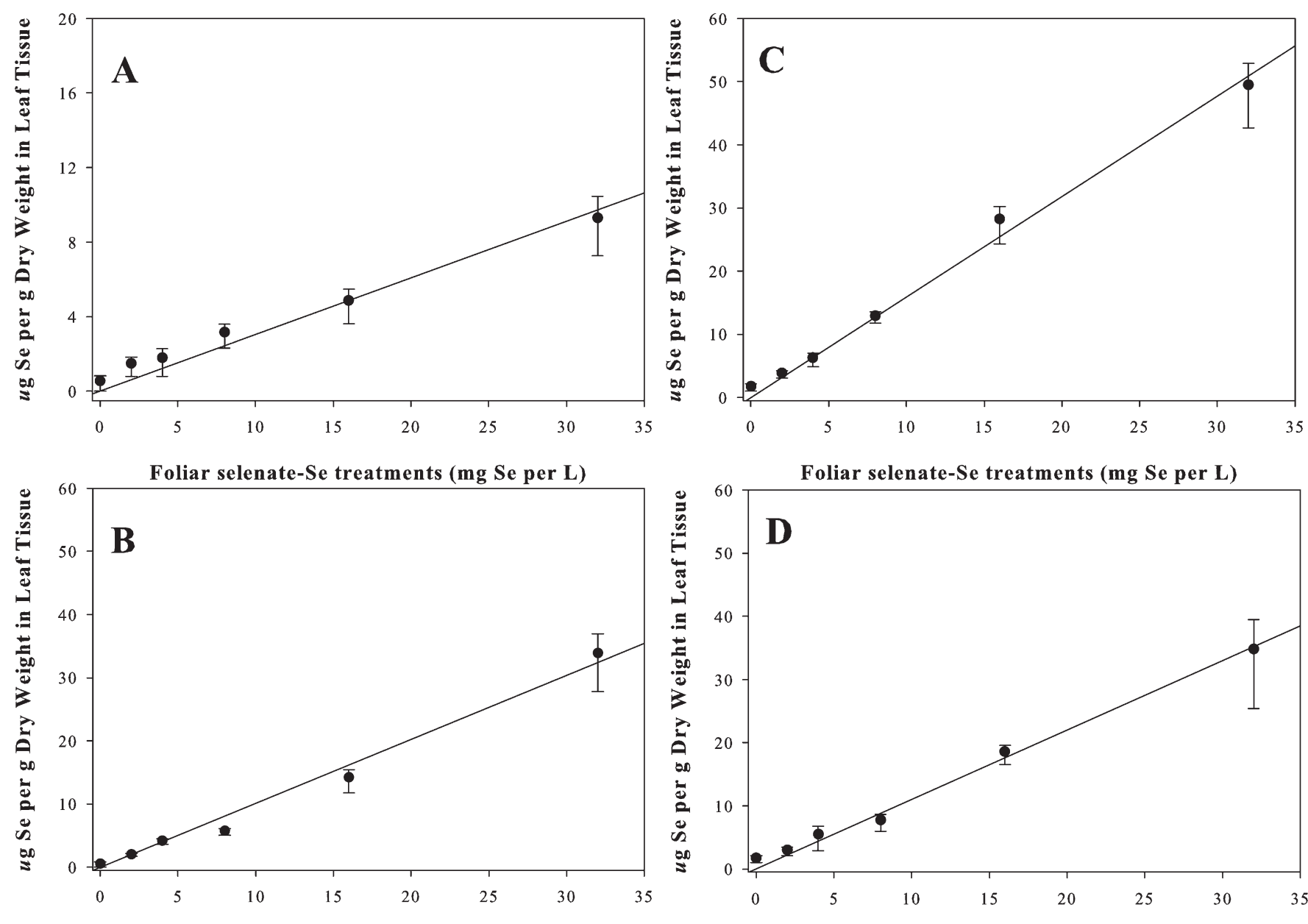

Foliar selenite-Se treatments (mg Se per L)

Foliar selenite-Se treatments (mg Se per L)

Fig. 2. Selenium (Se) accumulation in the leaf tissue of 'Santo' cilantro under foliar applications of $0.0,2.0,4.0,8.0,16.0$ and $32.0 \mathrm{mg} \cdot \mathrm{L}^{-1} \mathrm{Se}$ in a growth chamber environment with Se applied as (A) sodium selenate [selenate-Se $=0.78+0.27$ (trt) $; R^{2}=0.89$ ] and as (B) sodium selenite [selenite-Se $=-0.64+1.04$ (trt); $\left.R^{2}=0.95\right]$, and in a field environment with Se applied as $(\mathbf{C})$ sodium selenate [selenate-Se $=1.22+1.54($ trt $) ; R^{2}=0.97$ ] and as $(\mathbf{D})$ sodium selenite [selenite$\left.\mathrm{Se}=0.99+1.06(\operatorname{trt}) ; R^{2}=0.91\right]$. Values represent treatment means with SE bars.

is converted to selenite-Se by ATP sulfurylase before incorporation into various selenoether amino acids. In most plant species, Se-amino acids replace corresponding Samino acids (Anderson and Scarf, 1983). The presence of Se in plant tissues deceased concentrations of S-containing glucosinolate compounds in Brassicas, thereby indicating the impact of $\mathrm{Se}$ on normal $\mathrm{S}$ metabolism (Charron et al., 2001). Selenium phytotoxicity occurs mainly from Se interferences with normal S metabolism (Mikkelsen et al., 1989), resulting in chlorosis and decreases in protein and dry matter synthesis (Mengel and Kirkby, 1987). There were visual symptoms of slight Se phytotoxicity when the tissues Se concentrations exceeded $25 \mu \mathrm{g} \cdot \mathrm{g}^{-1}$ Se DM for the basil in the chambers, 20 $\mu \mathrm{g} \cdot \mathrm{g}^{-1} \mathrm{Se} \mathrm{DM}$ for the basil in the field, and 30 $\mu \mathrm{g} \cdot \mathrm{g}^{-1} \mathrm{Se} \mathrm{DM}$ for the cilantro in the chambers and field. Foliar selenization strategies in herbal crops may therefore be a compromise between desired tissue Se concentrations for dietary supplementation and visual acceptance of tissue quality.

Previous reports have identified increases in shoot and root tissue $\mathrm{S}$ under increasing
selenate-Se treatment concentrations in nutrient solutions (Kopsell and Randle 1997a, 1997b, 1999; Lefsrud et al., 2006). In the current study, $\mathrm{S}$ in the shoot tissue of basil and cilantro did not change in response to increasing foliar applications of selenate-Se or selenite-Se (data not shown). It has been postulated that either selenate-Se or $\mathrm{Se}$ metabolites antagonize the repression of sulfate transporters by excess sulfate and other $\mathrm{S}$ metabolites, thereby increasing $\mathrm{S}$ uptake in the presence of elevated media $\mathrm{Se}$ (White et al., 2004). However, based on the results from this study, foliar Se applications may not cause increases in $\mathrm{S}$ concentrations in shoot tissues like in soil-applied or nutrient solution Se studies.

The U.S. Department of Agriculture nutrient database (U.S. Department of Agriculture, Agricultural Research Service, 2007) lists natural tissue Se values for dried basil and cilantro as 0.03 and $0.30 \mu \mathrm{g} \cdot \mathrm{g}^{-1} \mathrm{Se} \mathrm{DM}$, respectively. Foliar applications of selenate$\mathrm{Se}$ and selenite-Se to basil and cilantro in the current study increased tissue Se concentrations far above these reported values. The packing density listed in the nutrient database for dried, milled basil is $4.5 \mathrm{~g} / 15 \mathrm{~cm}^{3}$ (roughly equal to 1 tablespoon). Supplementation of 100 to $150 \mu \mathrm{g} / \mathrm{d}$ Se would be enough to raise dietary Se to levels associate with health benefits (Finley, 2007). Consumption of $15 \mathrm{~cm}^{3} / \mathrm{d}$ of the selenized basil from the 16 $\mathrm{mg} \cdot \mathrm{L}^{-1} \mathrm{Se}$ foliar treatment in the current study would supplement dietary levels with close to $100 \mu \mathrm{g} / \mathrm{d}$ Se. This indicates that small quantities of selenized herbal tissue may have the potential for a positive dietary impact when consumed on a regular basis.

Results from the current study indicate the potential to selenize basil and cilantro shoot tissues through foliar applications of different Se forms. Selenization could be achieved under controlled environments and field environments. The response of basil and cilantro tissues to foliar Se applications may indicate the potential to modulate herbal tissue Se concentrations for Se supplementation in human diets.

\section{Literature Cited}

Adriano, D.C. 1986. Selenium, p. 390-420. In: Trace elements in the terrestrial environment. Springer-Verlag, New York, NY. 
Anderson, J.W. and A.R. Scarf. 1983. Selenium and plant metabolism, p. 241-275. In: Robb, D.A. and W.S. Pierpoint (eds.). Metals and micronutrients: Uptake and utilization by plants. Academic Press, New York, NY.

Baum, M.K., G. Shor-Posner, S. Lai, G. Zhang, H. Lai, M. Fletcher, H. Sauberlich, and J.B. Page. 1997. High risk of HIV-related mortality is associated with selenium deficiency. J. Acquir. Immune Defic. Syndr. Hum. Retrovirol. 15:370-374.

Brown, T.A. and A. Shrift. 1982. Selenium: Toxicity and tolerance in higher plants. Biol. Rev. Camb. Philos. Soc. 57:59-84.

Charron, C.S., D.A. Kopsell, W.M. Randle, and C.E. Sams. 2001. Sodium selenate fertilisation increases selenium accumulation and decreases glucosinolate concentration in rapid-cycling Brassica oleracea. J. Sci. Food Agr. 81:962-966.

Clark, L.C., B. Dalkin, A. Krongrad, G.F. Combs, B.W. Trunbull, E.H. Slate, R. Witherington, J.H. Herlong, E. Janosko, D. Carpenter, C. Borosso, S. Falk, and J. Rounder. 1998. Decreased incidence of prostate cancer with selenium supplementation: Results of a doubleblind cancer prevention trial. Br. J. Urol. 81:730-734.

Combs G.F., Jr. and W.P. Gray. 1998. Chemopreventative agents: Selenium. Pharmacol. Ther. 79:179-192.

Fang, Y., L. Wang, Z. Xin, L. Zhao, X. An, and Q. Hu. 2008. Effect of foliar application of zinc, selenium, and iron fertilizers on nutrient concentrations and yield of rice grains in China. $\mathrm{J}$. Agr. Food Chem. 56:2079-2084.

Finley, J.W. 2007. Increased intakes of seleniumenriched foods may benefit human health. J. Sci. Food Agr. 87:1620-1629.

Germ, M., V. Stibilj, J. Osvald, and I. Kreft. 2007. Effect of selenium foliar applications on chicory (Cichorium intybus L.). J. Agr. Food Chem. 55:795-798.

Gissel-Nielsen, G., U.C. Gupta, M. Lamand, and T. Westermarck. 1984. Selenium in soils and plants and its importance in livestock and human nutrition. Adv. Agron. 37:397-461.
Hawkesford, M.J. and F.-J. Zhao. 2007. Strategies for increasing the selenium content of wheat. J. Cereal Sci. 46:282-292.

Hoagland, D.R. and D.I. Arnon. 1950. The water culture method for growing plants without soil. Calif. Agricultural Expt. Sta. Circ. No. 347.

Ip, C. and D.J. Lisk. 1994. Characterization of tissue selenium profiles and anticarcinogenic responses in rats fed natural sources of selenium-enriched products. Carcinogenesis 15:573-576.

Kopsell, D.A. and D.E. Kopsell. 2006. Selenium, p. 515-550. In: Barker, A.V. and D. Pilbeam (eds.). Handbook of plant nutrition. CRS PressTaylor \& Frances Group, Boca Raton, FL.

Kopsell, D.A. and W.M. Randle. 1997a. Selenate concentration affects selenium and sulfur uptake and accumulation by 'Granex 33' onions. J. Amer. Soc. Hort. Sci. 122:721-726.

Kopsell, D.A. and W.M. Randle. 1997b. Short-day onion cultivars differ in bulb selenium and sulfur accumulation which can affect bulb pungency. Euphytica 96:385-390.

Kopsell, D.A. and W.M. Randle. 1999. Selenium accumulation in a rapid-cycling Brassica oleracea population responds to increasing sodium selenate concentrations. J. Plant Nutr. 22:927937.

Korpela, H. 1993. Selenium in cardiovascular diseases. J. Trace Elem. Electrolytes Health Dis. 7:115.

Lefsrud, M.G., D.A. Kopsell, D.E. Kopsell, and W.M. Randle. 2006. Kale carotenoids are unaffected by, whereas biomass production, elemental concentrations, and selenium accumulation respond to, changes in selenium fertility. J. Agr. Food Chem. 54:1764-1771.

Mayland, H.F., L.F. James, K.E. Panter, and J.L. Sonderegger. 1989. Selenium in seleniferous environments, p. 15-50. In: Jacobs, L.W. (ed.). Selenium in agriculture and the environment. Amer. Soc. Agron.-Soil Sci. Soc. Amer., Madison, WI.

Mengel, K. and E.A. Kirkby. 1987. Principles of plant nutrition. 4th Ed International Potash Institute, Bern, Switzerland.
Mikkelsen, R.L., A.L. Page, and F.T. Bingham. 1989. Factors affecting selenium accumulation by agricultural crops, p. 65-94. In: Jacobs, L.W. (ed.). Selenium in agriculture and the environment. Amer. Soc. Agron.-Soil Sci. Soc. Amer., Madison, WI.

Oldfield, J.E. 1991. Some implications of selenium for human health. Nutr. Today 4:6-11.

Poggi, V., A. Arcioni, P. Filippini, and P.G. Pifferi. 2000. Foliar application of selenite and selenate to potato (Solanum tuberosum): Effect of a ligand agent on selenium content of tubers. J. Agr. Food Chem. 48:4749-4751.

Reilly, C. 1998. Selenium: A new entrant into the functional food arena. Trends Food Sci. Technol. 9:114-118.

Ryan-Harshman, M. and W. Aldoori. 2005. The relevance of selenium to immunity, cancer, and infectious/inflammatory diseases. Can. J. Diet. Pract. Res. 66:98-102.

Smrkolj, P., V. Stibilj, I. Kreft, and M. Germ. 2006. Selenium species in buckwheat cultivated with foliar addition of $\mathrm{Se}(\mathrm{VI})$ and various levels of UV-B radiation. Food Chem. 96:675681.

Stibilj, V., I. Kreft, P. Smrkolj, and J. Osvald. 2004. Enhanced selenium content in buckwheat (Fagophyrum esculentum Moench) and pumpkin (Cucurbita pepo L.) seeds by foliar fertilisation. Eur. Food Res. Technol. 219:142-144.

U.S. Department of Agriculture, Agricultural Research Service. 2007. USDA National Nutrient Database for Standard Release, SR20. Nutrient Data Laboratory home page. 1 May 2008. $<$ http://www.ars.usda.gov/ba/bhnrc.ndl $>$.

U.S. Environmental Protection Agency. 1996. Microwave assisted acid digestion of siliceous and organically based matrices, Method \#3052. U.S. EPA, Washington, DC.

White, P.J., H.C. Bowen, P. Parmaguru, M. Fritz, W.P. Spracklen, R.E. Spiby, M.C. Meacham, A. Mead, M. Harriman, L.J. Trueman, B.M. Smith, B. Thomas, and M.R. Broadley. 2004. Interactions between selenium and sulfur nutrition in Arabidopsis thaliana. J. Expt. Bot. 55:1927-1937. 